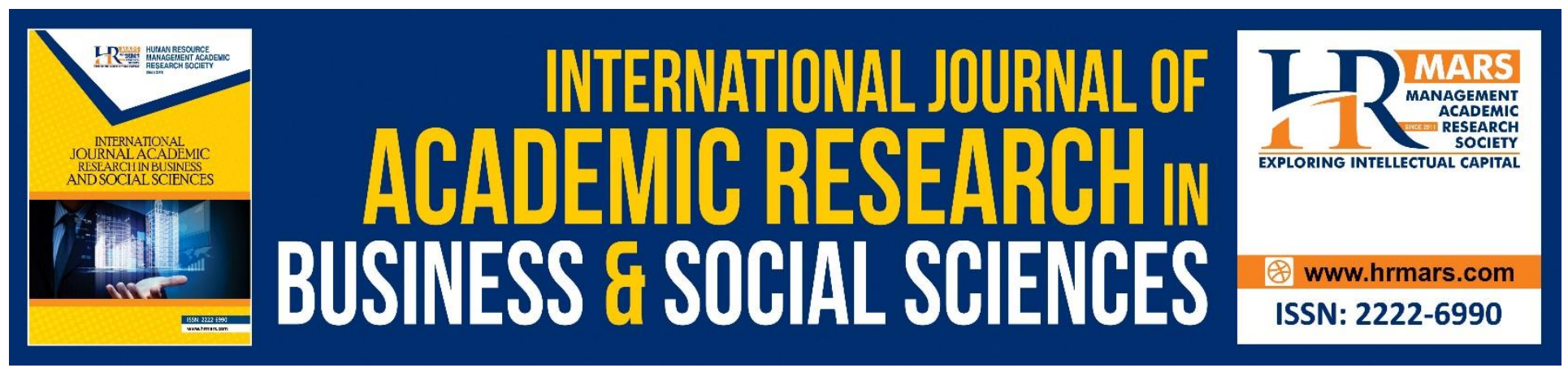

\title{
Enhancing Investors Knowledge through the New Auditor's Report Requirement: The Underpinning Theories
}

\author{
Ummi Junaidda Hashim, Norsiah Ahmad, Zalailah Salleh
}

To Link this Article: http://dx.doi.org/10.6007/IJARBSS/v8-i12/5063

DOI: $10.6007 /$ IJARBSS/v8-i12/5063

Received: 18 Oct 2018, Revised: 22 Nov 2018, Accepted: 17 Dec 2018

Published Online: 29 Dec 2018

In-Text Citation: (Hashim, Ahmad, \& Salleh, 2018)

To Cite this Article: Hashim, U. J., Ahmad, N., \& Salleh, Z. (2018). Enhancing Investors Knowledge through the New Auditor's Report Requirement: The Underpinning Theories. International Journal of Academic Research in Business and Social Sciences, 8(12), 658-668.

Copyright: (C) 2018 The Author(s)

Published by Human Resource Management Academic Research Society (www.hrmars.com)

This article is published under the Creative Commons Attribution (CC BY 4.0) license. Anyone may reproduce, distribute, translate and create derivative works of this article (for both commercial and non-commercial purposes), subject to full attribution to the original publication and authors. The full terms of this license may be seen

at: http://creativecommons.org/licences/by/4.0/legalcode

Vol. 8, No. 12, 2018, Pg. 658 - 668

http://hrmars.com/index.php/pages/detail/IJARBSS

JOURNAL HOMEPAGE

Full Terms \& Conditions of access and use can be found at http://hrmars.com/index.php/pages/detail/publication-ethics 


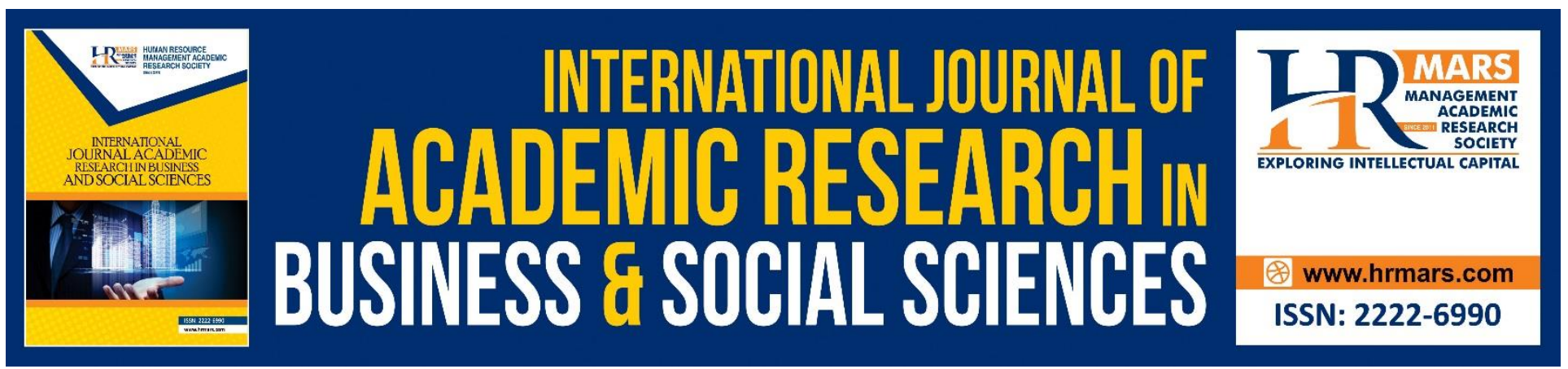

\title{
Enhancing Investors Knowledge through the New Auditor's Report Requirement: The Underpinning Theories
}

\author{
*Ummi Junaidda Hashima ${ }^{\text {, Norsiah Ahmad }}{ }^{\text {, }}$ Zalailah Salleh ${ }^{b}$ \\ a School of Accounting, Faculty of Economy and Management Science, Universiti Sultan Zainal \\ Abidin, Gong Badak Campus, 21300 Kuala Nerus, Terengganu, Malaysia \\ ${ }^{b}$ School of Maritime Business and Management, Universiti Malaysia Terengganu, \\ 21300 Kuala Nerus, Terengganu, Malaysia \\ *Correspondence Author: junaidda@unisza.edu.my
}

\begin{abstract}
This paper offers discussions towards the investors on the new audit report requirement imposed by the International Auditing and Assurance Standards Board (IAASB) in the recent years. The auditing has evolved over the period due to the advancement and the need of the global economy. The regulators and practitioners view that the new audit report as a tool that providing more to the investors including of increasing the transparency of information and audit quality. The new audit report requirement on ISA 701, Communicating Key Audit Matters (KAMs) has required more disclosure from the auditor by reporting the most significant matters in the audit of financial statements for the current period. The three underpinning theories; agency theory, knowledge-based theory of a firm and communication theory are discussed in supporting the theoretical of the new auditor's report.
\end{abstract}

Keywords: Audit, New Auditor's Report, Key Audit Matters (Kams), Transparency

\section{Introduction}

Auditing has been identified as the pillar of the business world where the economy of a market is assisted through the audit process. The growing of the business is in line with the importance to have an audit process, objectively in financial audit. The financial statements of the company are required to be verified by an independent auditor. The auditing process is to produce a verifiable and faithful representation of the financial information as highlights in the Conceptual Framework of Financial Reporting (2018). The early objective of audit purpose is for detecting the companies' fraud but purpose has been evolved from time to time due to the expansion of market and business. 


\section{The evolution of audit}

During the early period of the market, the stages of the development and evolution of audit are different for each market. For example, the Greece market has been documented as one of the market beginners that required to have an audit as early of 500-300 B.C. However, the auditing process for the time only limit to the verification process by the accountants including on accounting records and budget reports (Costouros, 1978). The auditing in U.S.A. has been prompted after the stock market crash during 1929 and upon that time, it has become compulsory. Securities and Exchange Commission (SEC) has been created for promulgating accounting standards and monitor auditor's role. Britain was in advanced than U.S. which is as early of seventieth and eighteenth century. The first act on the need of audit has been discovered in England with the passage of Registered Companies Act of 1862 (Watts \& Zimmerman, 1983).

The development of audit holds a direct relationship between the business and economy of a market. In line with Antle (1982) who labels that auditor as an economic agent. The audit market has been actively expanded during the industry revolution at the seventieth and eighteenth century where industry revolution as the period that has accelerated all structures including the economy (Crafts, 1977). Thereafter of the industry revolution, the auditor's role had been changed to another comprehensive role (Zanden \& Zanden, 2013).

The PricewaterhouseCoopers (2015) reports that at the period of 1800 s, audit report in London was less than 50 words that provide direct meanings.

A sample of audit report at 1895 as follows:

"We have to report that we have examined the above Balance Sheet with the accounts and vouchers relating thereto at.... and with the accounts received from branches and certify the same to be correct. We have certified the balance of cash at bankers and in hand."

Signed, A. N. Accountant

London: 26 February 1895

The contents and the length of the auditor's report are always improved from time to time in line with the advancement and the need of the modern economy by strengthening the auditing standards.

As one of the Asian markets and in developing economy, Malaysia has begun its audit practice prior to the independence and this started during British Colonial. The economic activities during the historical periods were focused on the tin mines and rubber estate and these activities had enforced the need of an audit that rose due to the separation of ownership and management (Ali, Haniffa, \& Hudaib, 2006).

For the recent years, the Companies Act 2016, Section 248(1) required the directors of each company shall prepare financial statements within six months period from its financial year end. Section 248(2) provides the following requirement:

"The financial statements referred in subsection (1) shall ne dully audited before the financial statements are sent to every member.

That requirement is a must whereby the financial statements of the company must be verified by an approved company's auditor. 
INTERNATIONAL JOURNAL OF ACADEMIC RESEARCH IN BUSINESS AND SOCIAL SCIENCES

Vol. 8, No. 12, Dec, 2018, E-ISSN: 2222-6990 @ 2018 HRMARS

\section{The phenomenon on audit crisis}

\section{ISA 200}

The auditing standard, ISA 200 highlights the purpose of conducting the audit as follows;

a) To obtain reasonable assurance about whether the financial statements as a whole are free from material misstatement, whether due to fraud or error, thereby enabling the auditor to express an opinion on whether the financial statements are prepared, in all material respects, in accordance with an applicable financial reporting framework; and

b) To report on the financial statements, and communicate as required by the ISAs, in accordance with the auditor's findings.

(ISA 200, paragraph 11)

The findings of the engagement will produce by an independent auditor through the auditor's report. The true colors and pictures of their audited clients need to represent in the auditors' findings. However, there are occasionally where the auditors unable to report them transparently on the correct situation of the audited company due to some reasons and motifs. The starter of the insensitive on the transparent issues has contributed to the serious economy problem such as the corporate collapse, white-collar crime, financial scandals, governance disputes and others (Hill, 2002).

\section{Financial scandals and audit}

Despite of having the accounting and auditing standards, the financial scandals continuously hit the market either locally or globally. It shows as the existing practices are still not powerful to control the situations. The financial scandals had caused a bad impact to the auditing profession itself. It also effects on few major areas of economy, social and politic (Sridharan, Dickes, \& Caines, 2002).

The unpredicted case on the financial scandals had occurred for the past two decades. It was a case of Enron, a U.S. company. The Enron scandal had involved many victims. It affected about 4,500 individuals who lost their careers due to bankruptcy of the company. The world has been awakened by the shredded documents of Enron. Enron Corporation eventually led to the bankruptcy during the year 2001 when the American energy company suffering from the audit failure by Arthur Andersen. At that time, Arthur Andersen was one of the five largest audit and accountancy firm in the world. The Enron case had a depressing effect on the stock market and the downturn of U.S. economy (Sridharan et al., 2002). Lesson learnt on the Enron disaster is strengthen the external monitoring role of the company's auditor (Hill, 2002). The Sarbanes-Oxley Act (2002) is the direct effect from this scandal.

The developing country such as Malaysia is not excepted from having such corporate scandals. The company of Perwaja Steel, Transmile Group Bhd, Oilcorp Bhd, Megan Media Holdings Bhd were among the famous cases of corporate scandals that occurred due to the lack of transparency of auditor in discharging their roles. The appointed auditors who are supposed to report on the companies' health had acted the vice versa.

The audit market has been growing over the time when the latest record for July 2018 shows that the total number of audit firms for Malaysian market are 1,472 firms. A report from 
Theedgemarket.com during April 2018, revealed that the Securities Commission has reprimanded and fined an auditor at medium size audit firm for RM225,00 due to in compliance with auditing standards ("SC reprimands, fines auditor RM225,000 for poor quality work," 2018). The accused auditor had not performed certain audit procedures on fixed deposits, goodwill, inventories and other receivables

Auditors have been finger pointed as player of important role in the scandal process. For any of the recent headlines of accounting failures have led some people to question the thoroughness of audits done (Levitt, 1998). For each of the economic and financial crisis will bring many shortcomings to the entire economic system including the auditor's work whereby the certified information provide by auditor will influence the decision made by the end users of the financial accounting information (Alexandra-Laura, 2017). This is in line as Abdolmohammadi and Rhodes, (2002) provide that the auditor and accountant are among the responsible parties that will assist to boost the country's wealth.

This market phenomenon arose due to few reasons as either due to lack of regulation or low penalty imposed by the regulatory bodies on the lack of compliance by the auditors. The regulators have responded on this matter by strengthening the role of auditor through enhancing auditing standards.

\section{Reshaping of audit to the need of global economy}

Auditing is important in assuring the reliability of the financial information of the company. More important than that, it assists the growth of the capital market through the economic impact of the audited financial statement. It believes that the audited financial statements will serve as a basis that enables to influence the decision making of the investors (Asare \& Wright, 2012; Salleh, Stewart, \& Manson, 2006). Thus, it is inevitable that the auditor's report is a significant tool for investors in their decision towards the company. Ashton, Willingham, \& Elliott (1987) have identified that the investors are in uncertainty mode while waiting for the information from the annual report particularly information on auditor's report. This has shown that the reports are highly important to them in assisting them to make their best investment decision.

To ensure the information are free from negotiating and not being compromising, the transparency level must be the main concerned of the auditor and should always be monitored by the audit team. When the transparency level increase, the level of information disclosure will also increase, thus the final outcome will produce high quality audit. The market has observed that quality of audit has been threatened in the recent years and this concern come from users of the financial statements. The question "did the auditor compromising the audit quality?" have been raised from the stakeholders when the financial scandals occurred. Deloitte (2016) reports that the users have demanded on more information from auditor's report which offers high transparency level and gives more insights on the audit. Many scholars argue that the existing practice of auditor's report with "pass" or "fail" report offers limited information to the investors. Furthermore, there will be no other reporting information when the company received the unqualified opinion and the safety mode on by the investors. Unluckily, at the moment, the auditors hold a bundle of information on their hands with material and immaterial. The problems of information gap arise in this situation (Lawson, O'Hara, \& Spencer, 2017). 
The criticism over the existing practice of audit report has triggered the regulators to do some improvements on the current practice. The international standard setters and regulators including of International Auditing and Assurance Standards Board (IAASB), United Kingdom's Financial Reporting Council (FRC), and Public Company Accounting Oversight Board (PCAOB) had revised, updated and added a new auditing standard in an effort to strengthen the audit and the reporting activities.

The new independent auditor's report has come into implementation after few years of developing process. The reasons are rooted from the recent financial crisis which was questioned by the investors on the role of auditors regarding the standardization and law of the information reported in the independent auditor's report. Those have been noticed by the IAASB Chairman and subsequently emphasised the need to have more informative auditor's report. Following to the statement of the IAASB Chairman, during the year of 2011, a consultation has been launched. During July 2013, an Exposure Draft (ED) "Reporting on Audited Financial Statements: Proposed New \& Revised International Standards on Auditing", has been generated and open for comments. from the comments and discussions, in January 2015, the IAASB has released its new and revised Auditor Reporting standards known as ISA 701, Communicating the Key Audit Matters in Independent auditor's report. The existence of tomorrow audit is triggered by the scandals that have boomed the market without prior notice.

\section{Amendments and Regulating of the new auditing standards}

For the current period, the revision on the existing standards of auditing and the introducing of new standard has been issued by IAASB as presented in Table 1 as follows:

Table 1: Revised and new auditor reporting standards

\begin{tabular}{|r|}
\hline \multicolumn{2}{|l|}{ Revised Standards } \\
\hline 1. ISA 700 (Revised), Forming an Opinion and Reporting on Financial Statements \\
\hline 2. ISA 705 (Revised), Modifications to the Opinion in the Independent Auditor's Report \\
\hline 3. ISA 706 (Revised), Emphasis of Matter Paragraphs and Other Matter Paragraphs in the \\
Independent Auditor's Report; with Governance
\end{tabular}

ISA 701, Communicating Key Audit Matters in the Independent Auditor's Report

Communicating KAMs in the Independent Auditor's Report which is mandatory for all listed companies effective from 15 December 2016 and onwards (IAASB, 2015). The Malaysian Institute of Accountant (MIA) is a statutory body that regulates and monitor any matters of accounting in Malaysian market. For the KAMs, the MIA has approved the standard to be used in Malaysia market. Companies with the year ended of 31 December 2016, will be the first batch that apply the new standard of ISA 701. Prior to the date of 15 December 2016, there is only a common independent auditor's report without the separate section of KAMs. Therefore, the new regime of independent auditor's report only can be found after the date. The auditors need to communicate the KAMs in the 
INTERNATIONAL JOURNAL OF ACADEMIC RESEARCH IN BUSINESS AND SOCIAL SCIENCES

Vol. 8, No. 12, Dec, 2018, E-ISSN: 2222-6990 C 2018 HRMARS

independent auditor's report by reporting the most important matters on the audit of financial statements for the current period based their judgment and discussion with other governance boards. Diagram one below provides the flow in the process of communicating the KAMs in the independent auditor's report.

\section{Diagram 1: Determining and Communicating of Key Audit Matters}

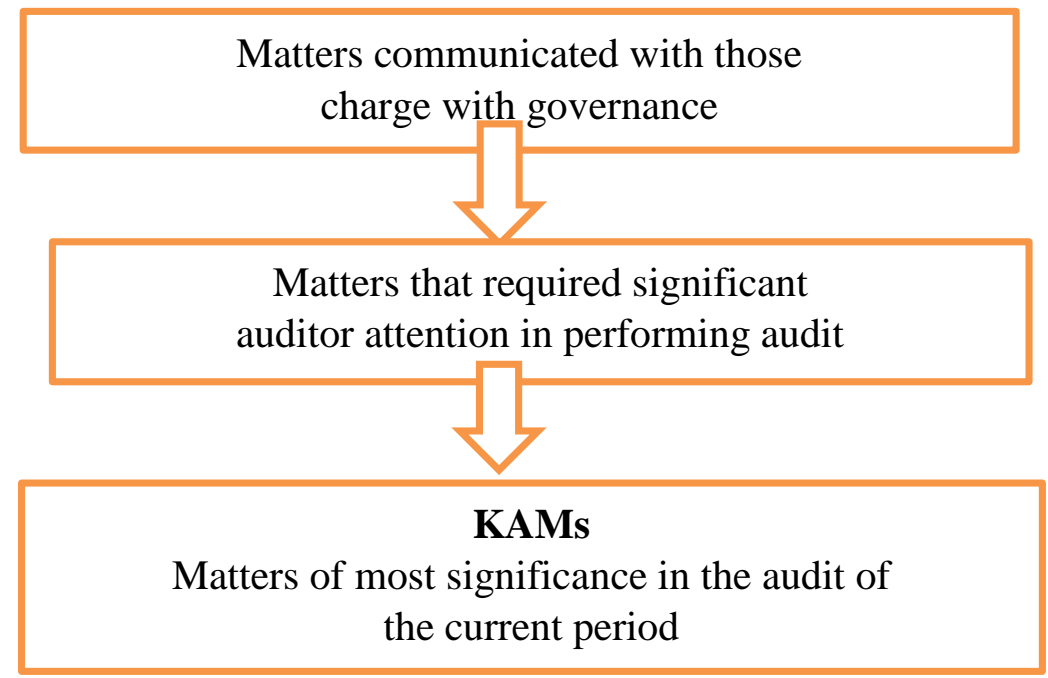

Sources, Determining and Communicating Key Audit Matters (“KAM”)

IASB June 2016

\section{Discussion on Underpinning theories of KAMs Agency Theory}

When a business is managed by an agent on behalf of its owner or principal, the principal-agent relationship is arose due to the separation of ownership and control (Fama \& Jensen, 1983). The agent possesses more information about the business as compared to its principal or the capital provider. Thus, the problem of imbalance information occurred between the principal and the agent. This situation known as asymmetry information that results in two major agency problems including of moral hazards and adverse selection. An auditor has been appointed as an external party to combat that two asymmetry information problems between the principal and agent and it is supported by agency theory under the agency cost function.

Auditing serves as a monitoring on the contractual relationships between the company with its shareholders, managers, debt holders and employees (Zerni, 2009). In depth, auditing provides beneficial to all of its stakeholders for their decision-making purpose. Audits developed as a means of protecting shareholders' interests. 
The appointment of an auditor in the recent years creates further agency relationship which in turn has impaired the trust and produces new issues relating to the independence (The Institute of Chartered Accountant of England and Wales, 2005). That's has resulted the change of auditor's role in response to global demand. The rule of an auditor to be independent is required in the purpose of controlling the audit quality (Ali \& Lee, 2008). Corporate scandals storms that hit on the recent years has called the improvements on role, task and responsibility of auditor. Some of the past studies found a positive relationship between independence of audit and audit quality (Baotham \& Ussahawanitchakit, 2009). Therefore, audit quality is not a stand-alone matter. Basically, it arose from the principal-agent relationship, information asymmetry, separation of ownership and control which is under the roof of agency theory. The communicating KAMs in the Independent Auditor's Report is responding to the need of the users and to enhance the quality of the auditor's report.

Principally, from the discussion above, the existence of the requirement on KAMs has been arising from the agency theory as the need to enhance the quality of the engagement. The new KAMs is as the new mechanism to enhance the key players in the agency theory and as the new tool that possibly will improve the audit quality dimension for all markets. The outcome of this implementation is beneficial to the investors whereby will receive the high quality of auditor's report that will reflect their decision-making process.

\section{Knowledge based theory of a firm and resource dependency theory}

Knowledge based theory of a firm has been initially developed by Penrose, 1959. The theory considered that knowledge as the most significant resources to the firms. Penrose (1959) as cited by Kor \& Mahoney (2004) has emphasised that the efficient of the firms in managing the resources will assist the firm to obtain higher return. And yet Curado (2006) has argued knowledge would not be depreciated over time but it can generate increase in return. As the efficient in managing the resources, thus the important information will be addressed by the company in its financial report. Hence, this would facilitate investors in their decision making. The decision to invest by the investor would provide advantages on the company's return and this supporting the argument of Curado (2006).

In explaining the resources of a firm, there are various of firm's resources that would generate benefits to the firm that could develop ideas, experience and knowledge (Kor \& Mahoney, 2004). The governance parties are among the resources that possess by a firm. The governance member of the audit committee is among the tools of the company. The literature has affirmed that the audit committee plays an important role in the monitoring and reporting process of the companies (Chien, Mayer, \& Sennetti, John, 2010; Hashim \& Rahman, 2011). For example, their characteristics are enabled to turn up the performance of the companies and maintain the quality of the reporting. A recent study has found that more expertise members sit in the committee and more frequent of the meetings would able to reduce the possibility of occurrence restatement of the financial restatement (Wan Mohammad, Wasiuzzaman, Morsali, \& Mohd Zaini, 2018). The knowledgeable audit committee members will uphold the good attributes that assist to improve the performance, reporting, and disclosure of the company. 
With regards to the ISA701, the governance parties play the most juf role in raising the probable issues of KAMs. Therefore, the knowledge-based theory of a firm is holding a direct relationship with the resource dependency theory. The knowledge possesses by the audit committee member is as the important resources of the company that enable them to highlight the possible disclosure of KAMs to the investors. The compliance of KAMs is in supporting the theory of knowledge-based theory of a firm and resource dependency theory which are the resources of the firm as the knowledge that provides an economic return from the informativeness of the financial information to the investors and other stakeholders.

\section{Communication Theory}

Communication theory has defined as a set of concepts and relationship statements that enables one to understand, describe, explain, evaluate, predict and control the phenomena (Cragan \& Shields, 1998). The communication of accounting information and auditing findings is a part of the ideas of the communication theory. The communication of audit has been developed as a research tool to the investors and also provides information on company's health (Booth, 1989). Chambers 1966 (pages 166-7), as cited by (Lee, 1982) defines that;

".... Communication between persons is a matter of transmitting significance, of establishing in the mind of another what one has observed, recorder and otherwise processed ......"

Thus, the transmission of the message is further required an evaluation and processes by the expert of the accountant and auditor. The 'communication audit' is a part of the process that enables the investors of the company to understand through the descriptions and explanations in the auditor's report. However, the theory of communication is not successfully applied in the communication audit since auditor's report provides a page of the report that stating pass or fail report only (Mock et al., 2013). This offers limited information to stakeholders in their decision-making process.

The more of the disclosure will assist the investors to understand better on the condition of the company. In a company, communication of information is a vital tool to update the third parties on all the outcomes and events in the companies (Brennan \& Conroy, 2013) and more importantly updating on the financial matters. This is in agree with the novice argument of Lee (1982) that the effective of the process of accounting quantification and the resultant data will not be useful until they are communicated adequately. Therefore, enhancing the contents of auditor's report through the KAMs as a method to improve communicating of financial information to the users. Communicating of more information disclosures enable the investors to decide the best for their investment decisions.

\section{Conclusion}

The effect of the new standard on ISA 701, Communicating of the Key Audit Matters is required for more disclosure in the independent auditor's report of the company. The purpose is to increase the transparency, integrity and also enhance the audit quality. Adding the KAMs as the mandatory requirement in the auditor's report is as the new mechanism in the agency theory, communication theory and knowledge-based theory. Theoretically, the KAMs has been accepted as an updated regime in the independent auditor's report for the recent years and the reporting of it is viewed as interaction on the resource-dependency of the company. 
INTERNATIONAL JOURNAL OF ACADEMIC RESEARCH IN BUSINESS AND SOCIAL SCIENCES

Vol. 8, No. 12, Dec, 2018, E-ISSN: 2222-6990 @ 2018 HRMARS

\section{References}

Abdolmohammadi, M. J., \& Rhodes, J. E. (2002). The Influence of Accounting and Auditing on a Country's Economic Development. Review of Accounting and Finance, 1(3), 42-53.

Alexandra-Laura, M. (2017). Amendments to the Audit Report for the Review of International Standards on Auditing. "Ovidius" University Annals, Economic Sciences Series, XVII(1), 539-544.

Ali, A., Haniffa, R., \& Hudaib, M. (2006). Episodes in the Malaysian auditing saga. Managerial Auditing Journal, 21(7), 684-701. https://doi.org/10.1108/02686900610680495

Ali, A., \& Lee, T. H. (2008). Malaysia' s external auditing: The case of the better tool for analysis. International Journal of Business and Management, 3(9), 99-120.

Antle, R. (1982). The Auditor as an Economic Agent. Journal of Accounting Research, 20(2), 503527. https://doi.org/10.2307/2490884

Asare, S. K., \& Wright, A. M. (2012). Investors', auditors', and lenders' understanding of the message conveyed by the standard audit report on the financial statements. Accounting Horizons, 26(2), 193-217. https://doi.org/10.2308/acch-50138

Ashton, R. H., Willingham, J. J., \& Elliott, R. K. (1987). An Empirical Analysis of Audit Delay. Journal of Accounting Research, 25(2), 275. https://doi.org/10.2307/2491018

Baotham, S., \& Ussahawanitchakit, P. (2009). Audit independence, quality, and credibility: effects on reputation and sustainable success of CPAs in Thailand. International Journal of Business Research , 9(1). Retrieved from http://www.freepatentsonline.com/article/InternationalJournal-Business-Research/208535065.html

Booth, A. (1989). The Communications Audit: A Useful Management Tool? Managerial Auditing Journal, 4(2), EUM0000000001748. https://doi.org/10.1108/EUM0000000001748

Brennan, N. M., \& Conroy, J. P. (2013). Executive hubris: The case of a bank CEO. Accounting, Auditing \& Accountability Journal, 26(2), 172-195. https://doi.org/10.1108/09513571311303701

Chien, W., Mayer, R. W., \& Sennetti, John, T. (2010). Audit Committee Effectiveness in the Largest US Public Hospital: An Empirical Study. ACCOUNTING \& TAXATION, 2(1), 107-127. Retrieved from ftp://ftp.repec.org/opt/ReDIF/RePEc/ibf/acttax/at-v2n1-2010/AT-V2N1-2010-8.pdf

Costouros, G. J. (1978). AUDITING IN THE ATHENIAN STATE OF THE GOLDEN AGE. The Academy of Accounting Historians, 5(1), 41-50. Retrieved from http://www.jstor.org/stable/40697561

Crafts, N. F. (1977). Industrial Revolution in England and France: Some Thoughts on the Question,"Why was England First?" The Economic History Review, 30(3), 429-441.

Cragan, J. F., \& Shields, D. C. (1998). Understanding Communication Theory the Communicative Forces for Human Action. Boston: Allyn \& Bacon. Retrieved from https://philpapers.org/rec/CRAUCT

Curado, C. (2006). the Knowledge Based-View of the Firm: From Theoretical Origins To Future Implications. Igarss 2014. https://doi.org/10.1007/s13398-014-0173-7.2

Deloitte. (2016). Clear, transparent reporting: The new auditor's report. Retrieved from https://www2.deloitte.com/content/dam/Deloitte/ch/Documents/audit/ch-en-audit-newauditors-report.pdf

Fama, E. F., \& Jensen, M. C. (1983). SEPARATION OF OWNERSHIP AND CONTROL. The Journal of Law, 26(2), 301-325. 
Hashim, U. J. B., \& Rahman, R. B. A. (2011). Audit report lag and the effectiveness of audit committee among malaysian listed companies. International Bulletin of Business Administration, 10(10), 50-61. Retrieved from https://www.scribd.com/doc/65902120/AuditReport-Lag-and-the-Effectiveness-of-Audit-Committee-Among-Malaysian-Listed-Companies

Hill, J. G. (2002). Regulatory responses to global corporate scandals. Wisconsin International Law Journal, 23(20), 367-781. https://doi.org/10.3868/s050-004-015-0003-8

IAASB. International Standards on Auditing 701: Communicating Key Audit Matters in the Independent Auditor's Report, 1 Ifac $\S(2015)$.

Kor, Y. Y., \& Mahoney, J. T. (2004). Edith Penrose's (1959) Contributions to the Resource-based View of Strategic Management. Journal of Management Studies, 41(1), 183-191. https://doi.org/10.1111/j.1467-6486.2004.00427.x

Lawson, B. P., O'Hara, V., \& Spencer, A. W. (2017). Updates and Comparisons Regarding Changes to the Audit Reporting Model in the United States, United Kingdom, and European Union. The Journal of Corporate Accounting \& Finance, (July/August 2017), 9-14.

https://doi.org/10.1002/jcaf

Lee, T. A. (1982). Chambers and Accounting Communication. Abacus, 18(2), 152-165. https://doi.org/10.1111/j.1467-6281.1982.tb00032.x

Levitt, A. (1998). The "Numbers Game." Chairman SEC, https://www.sec.gov/news/speech/speecharchive/1998/spch220.txt.

Mock, T. J., Bédard, J., Coram, P. J., Davis, S. M., Espahbodi, R., \& Warne, R. C. (2013). The audit reporting model: Current research synthesis and implications. Auditing, 32(SUPPL.1), 323-351. https://doi.org/10.2308/ajpt-50294

PricewaterhouseCoopers. (2015). The Revolution in Audit Reports, (August).

Salleh, Z., Stewart, J., \& Manson, S. (2006). The Impact of Board Composition and Ethnicity on Audit Quality: Evidence from Malaysia Companies. Malaysian Accounting Review, 5(2), 61-83.

SC reprimands, fines auditor RM225,000 for poor quality work. (2018). Retrieved August 7, 2018, from http://www.theedgemarkets.com/article/sc-reprimands-fines-auditor-rm225000-poorquality-work

Sridharan, U. V., Dickes, L., \& Caines, W. R. (2002). The Social Impact of Business Failure: Enron. American Journal of Business, 17(2), 11-22. https://doi.org/10.1108/19355181200200006

The Institute of Chartered Accountant of England and Wales. (2005). Agency theory and the role of audit. ICAEW.

Wan Mohammad, W. M., Wasiuzzaman, S., Morsali, S. S., \& Mohd Zaini, R. (2018). The Effect of Audit Committee Characteristics on Financial Restatements in Malaysia. Journal of Asia-Pacific Business, 19(01), 1-19. https://doi.org/10.1080/10599231.2018.1419043

Watts, R. L., \& Zimmerman, J. L. (1983). Agency Problems, Auditing, and the Theory of the Firm: Some Evidence. The Journal of Law and Economics, 26(3), 613-633. https://doi.org/10.1086/467051

Zanden, P. Van Der, \& Zanden, P. M. Van Der. (2013). A Description of the Historical Developments in Standard Setting and Regulations for Auditors and the Audit Firms in an International Perspective. Eleven Journals, 2(June), 1-37.

Zerni, M. (2009). Essays on audit quality. OULU UNIVERSITY PRESS. University of Oulu. 